Special issue: The Relation of Social Pedagogy and Social Work

Article

\title{
Social pedagogy versus social work in a Swedish context
}

\author{
Elisabet Cedersund, ${ }^{1, *}$ (D) Lisbeth Eriksson, ${ }^{2}$ () Bibbi Ringsby Jansson, ${ }^{2}$ (D) \\ Lars A. Svensson ${ }^{2}{ }^{10}$ \\ ${ }^{1}$ Division of Ageing and Social Change, Department of Culture and Society, Linköping University, \\ SE-60174 Norrköping, Sweden \\ 2 Division of Social Work and Social Pedagogy, Department of Social and Behavioural Studies, University \\ West, SE-46186 Trollhättan, Sweden; Lisbeth.Eriksson.2@hv.se (L.E.); bibbi.ringsby.jansson@hv.se (B.R.J.); \\ lars.a.svensson@hv.se (L.A.S.) \\ *Correspondence: elisabet.cedersund@liu.se
}

How to Cite: Cedersund, E., Eriksson, L., Ringsby Jansson, B. and Svensson, L. A. (2021). Social pedagogy versus social work in a Swedish context. International Journal of Social Pedagogy, 10(1): 13. DOI: https://doi.org/10.14324/111.444.ijsp.2021.v10.x.013.

Submission date: 5 January 2021; Acceptance date: 1 September 2021; Publication date: 2 November 2021

\section{Peer review:}

This article has been peer-reviewed through the journal's standard double-blind peer review, where both the reviewers and authors are anonymised during review.

\section{Copyright:}

(C) 2021, Elisabet Cedersund, Lisbeth Eriksson, Bibbi Ringsby Jansson and Lars A. Svensson. This is an open-access article distributed under the terms of the Creative Commons Attribution Licence (CC BY) $4.0 \mathrm{https}: / /$ creativecommons.org/licenses/by/4.0/, which permits unrestricted use, distribution and reproduction in any medium, provided the original author and source are credited • DOI: https://doi.org/10.14324/111.444.ijsp.2021.v10.x.013.

\section{Open access:}

International Journal of Social Pedagogy is a peer-reviewed open-access journal.

\section{Abstract}

In Sweden there are several different professions that work within the welfare sector. Two of these are social pedagogues and socionoms. This article examines the similarities and differences between these professional fields by exploring four areas in more detail: education, the history of ideas and theory, research and practice. The results show that there are not only many differences but also some similarities. In practical work, social pedagogues and socionoms often work side by side and perform similar tasks. They are located in the same areas and often use the same methods. When it comes to the differences in educational history and current educations, they are large although they can also be found in, for example, the history of ideas. Furthermore, research in the various 
areas differs. In social pedagogy the interest has to a greater extent been focused on an understanding of the discipline through studies of the history of ideas, while in social work today one often focuses on studies of professional methods. Today's challenges in the welfare sector require new knowledge, ways of thinking and understanding. Here, social pedagogy with its philosophical roots and humanistic values can play an important role.

Keywords social pedagogy; social work; history of ideas; welfare sector; educational history; humanistic values

\section{Social pedagogy versus social work in a Swedish context}

The Swedish welfare system is based on general principles whereby all citizens must be given access to welfare services. These can be described as consisting of three parts: economic security (both welfare and social insurance; Sandermann, 2014); social security; and health. Sweden has traditionally had a strong public sector that has taken extensive social responsibility and provided its citizens with various welfare services. This is what has been characteristic of the Swedish model. Developments in recent decades have, however, led to civil society organisations and the private business sector becoming increasingly important, for example as providers of social services (Harding, 2012). This has been done by organisations, associations and companies who have agreed to undertake the provision of services that were previously imposed on the public sector.

In Sweden there are several different professions that are active in the welfare sector-socionoms ${ }^{1}$ and social pedagogues are two examples. Often, these professional categories work side by side and perform essentially similar tasks, as evidenced in some research reports (Eriksson and Cederlund, 2015; Eriksson and Hedman, 2018). However, today, from what we have found, there are no published reports on possibly different ways of thinking, acting and relating to their work tasks, based on their training. The boundaries have also been blurred between the academic degrees that exist at the time of writing. With a few exceptions, all social pedagogical programmes have been integrated with social work degrees. ${ }^{2}$ In order to investigate the potential differences and similarities depending on education, in terms of thinking and acting, the experiences of previously trained social pedagogues have been studied, but not those of socionoms (Cederlund, Eriksson, Ringsby Jansson and Svensson, 2020).

Hence, in Sweden social pedagogues and socionoms usually work on similar tasks, but a question we ask ourselves in this article is whether there are, after all, differences regarding practice and, if so, how they are manifested? A further question is whether the two professions and the two disciplines have the same origin, theoretical basis and perspective in terms of the history of ideas. What are the similarities and differences and what significance do they have? To investigate this in more detail, in this article we describe the conditions within social work and social pedagogy regarding education, the history of ideas and theory, research and practice.

Both social pedagogy and social work contain a variety of elements. They can be understood and explained as theoretical frameworks of thought based on the history of ideas or as practical activities. Linked to this is the academic degree that helps to shape both theory and practice. The degree is believed to have a major impact on how, for example, the practical work is carried out (see Cederlund et al., 2020). The degree shapes future welfare workers and gives them a foundation on which to base their professional careers. The research conducted in these areas affects both the content of the degrees but also individual social workers. ${ }^{3}$ By highlighting these four areas, a more comprehensive picture of social pedagogy and social work is revealed. Our starting point is the situation regarding social pedagogy, where we ourselves have conducted research and have the greatest insight. For comparative purposes, we also discuss research in social work in the above-mentioned areas and relate this to social pedagogy.

\section{Educational history of socionoms and social pedagogues}

The growth of social work education in Sweden can be traced to 1921, when the Institute for Social Policy and Municipal Education and Research was founded on the initiative of the Central Association 
for Social Work (CSA). The CSA was a women's initiative and one of the areas that particularly interested the association was to start vocational training for social workers. The training was conducted by the CSA for more than a quarter of a century (Swärd and Edebalk, 2017), and the first teachers were mainly women, active in philanthropic activities and involved in issues concerning people's everyday life situations. This formed the basis for the degree of BSc in Social Work at Stockholm University. During the post-war period, degree programmes in social work were established at schools of social work in Stockholm, Gothenburg, Umeå, Lund, Örebro and Östersund. The three-and-a-half-year programmes were carried out at these institutions and included two terms of internship (Thörn, 2017). In the 1970s the social work programmes were housed within the framework of the universities.

The development of a degree for social workers went towards more theoretical studies. Today, studies in social work are offered at many universities across Sweden. The course consists of a three-year programme and leads to a vocational degree as a socionom. The scope of the internship-related parts of the programme also varies between universities.

The first cohesive degree in social pedagogy in Sweden was introduced in 1959 at the Social Children and Youth Seminar in Stockholm. Students who completed the programme received a degree in social pedagogy. There was a great need for education in the field of activity and in 1970 a similar programme was started in Malmö (Regeringens Proposition, 1978/79, p. 197). In connection with higher education reforms in 1977, a degree in social pedagogy became a three-and-a-half-year local programme within the municipal universities in Stockholm and Malmö. Also as a part of the reforms, a new course of study called the Social Care Programme was established at 19 regional health care universities in Sweden. The new programme began in 1982 and offered specialisations in different groups, such as children and young people, elderly people and those with disabilities. The research connection of the new degree was related to the research area of social work, but in the investigation that preceded the change it was emphasised that the subject content of the degree could not be seen as identical to that of social work.

A new review was carried out in the early 2000s and resulted in most of the social care programme being organisationally moved from university colleges to the universities and becoming the degree of Bachelor of Social Science with a major in Social Work. In some universities specific specialisations were initially established as majors in social pedagogy. Today, none of these specialisations remain and social pedagogy only exists within the social work programme, as a feature of different courses or as elective courses at different levels. In Sweden, at the time of writing, it is not possible to defend a dissertation in social pedagogy, but it is possible to do so in social work, which is a major subject in all academic programmes that provide degrees in social work. What has the development been like for the two areas of knowledge?

\section{The social work degree is academicised while the social pedagogical programme is de-academicised}

The social work programmes have been increasingly academicised since the 1970s and have introduced more theoretical and research-based knowledge (Dellgran and Höjer, 2012; Meeuwisse and Swärd, 2016). The focus corresponds to some extent to trends and changes, with increased specialisation and differentiation, that have taken place in practical social work. At the same time, a certain consolidation has taken place as the research volume has increased. Journals have emerged in the discipline and the field of knowledge is discussed in national and international contexts. As for the major in social pedagogy, the development can be said to be reversed. If there is a great lack of programmes in social pedagogy at the academic level today, there are numerous programmes and courses with a social pedagogical focus at upper secondary and post-secondary education levels, at folk high schools and at private education providers. These are not academic programmes at university level, and there are large variations in scope and content. 


\section{The ideological traces of the two areas of knowledge within the programmes}

We can discern different traces of ideological development over time in both the social pedagogy-oriented programme and the content and focus of social work programmes - traces that partly coincide with or can be attributed to societal and social policy changes. In the historical description of the emergence of the degrees, one can see an oscillation between generalist education and specialisation, between a broader and a narrower understanding of social pedagogy and social work as theory, method and social practice. The subject definitions put forward by different representatives in the areas of knowledge also have partly different orientations (Sunesson, 2003).

The programme in Social Pedagogy that was conducted at the two training seminaries in Stockholm and Malmö, aimed to have the students contribute by creating conditions for socially vulnerable individuals and groups' socialisation and liberation. With the new merged social care education that was formed after the transition to municipal higher education, a demarcation was made between specific target groups. The complementarity between social care and social pedagogy is related to the professional approach in practice and is seen as an expression of people caring for one another. The different target groups that their work is aimed at may have different problems, needs and life situations, and the concrete design of the support work may vary, but the dialogical and relational approach was central, regardless of target group and would characterise the content of studies in social pedagogy. Madsen (2006), as one of the Nordic representatives of social pedagogy, provided a description of the subject development of social pedagogy with the help of concepts such as treatment, action and negotiation. These purpose orientations can also be discerned in the direction of the programmes and changes over time - not in the way that one orientation replaces the other when the programmes change, but rather in the way that they apply to a greater or lesser extent at the same time, with a focus that shifts over time and in relation to shifts in other areas of society, such as changes in the welfare society, with an increasing degree of individualisation and privatisation (Madsen, 2006; Swärd and Edebalk, 2017).

The education programme for the profession of social workers and the subject of social work development can be related to the Social Institute, where the first actual degrees were offered, while shorter practical courses had long existed within the framework of the Central Association for Social Work (Thörn, 2017). During the 1950s and 1960s education grew rapidly, and the professionalisation of social work became clear through the establishment of ethical guidelines, the internationalisation of education and on the knowledge required in order to be given authority as a social worker. After the higher education reforms in 1977, the subject of social work was established as an interdisciplinary postgraduate subject. In the undergraduate programme, elements from social methodology, which clearly characterised the previous degree, were integrated with subjects such as psychology, sociology, economics and law (Nygren, 2016). Social problems are the area of knowledge that can traditionally be said to form the basis of social work, but as the field has grown, different definitions have been formulated and there is no uniform definition of the subject (Brante, 2005). The question of the breadth of education and the degree of generalisation has been a subject of discussion among professors in the field. Depending on the model chosen by the higher education institution, the subject can emphasise both expertise in social conditions and attitudes, practical skills and the ability to assess a situation. All in all, however, it is stated that studies in social work must be dynamic in relation to societal changes. In recent years, an increased differentiation and specialisation can be seen, with specialisation-specific names for professorships, but there has also been a fragmentation of the subject (Nygren, 2016).

From the history of education described above, one can infer a social pedagogical knowledge that has long been and still is in demand by various organisations that work practically with socially vulnerable groups. However, this interest has had no direct equivalent in the field of education, at least not if we are talking about academics. Social pedagogical programmes started at a level close to practice, had an interlude at universities and colleges and now sit largely outside academia. Swedish developments seem to go in the opposite direction to some other countries, where, based on studies in social pedagogy, attempts are made to develop and improve practice, as is the case in countries such as the USA and Japan (Cedersund, Eriksson, Ringsby Jansson and Svensson, 2019a).

In contrast, social work has consolidated its role in the academic system, insofar as it is formally established, regulated and allocated specific resources, but not in such a way that there is consensus on the theoretical core of the subject. In addition to debates about the theoretical content of the subject, 
about evidence-based methods and specialisation or about the role of scientific knowledge in relation to empathic ability and practical professional skills, the discussion in recent years has been characterised by what professionalisation has entailed, how practical work should be designed and what the degree should contain. Research, education and practice are closely related and interdependent. At the same time, research is strongly linked to academia and requires a context in which research, education and development can be coordinated to strengthen knowledge in the field. Social pedagogy lacks this context in Sweden today. For social work, there is the formal context; there are also signs of both consolidation and success as well as the risk of disintegration.

\section{The history of ideas}

A discipline's grounding in the history of ideas, together with the history of education, is important for understanding the discipline's development and content. Either social pedagogy or social work are examined as theoretical fields, or as practices they can be discussed as two different discourses concerning the meaning of the concept: the particularistic and the universalistic. In a previous study, these two discourses have been studied in the field of social pedagogy, and research shows that these two can dominate in different times and places and that individuals, and of course groups of people, can deal with several discourses at the same time (Eriksson, 2006).

The two discourses contain different knowledge interests. The universalistic is based on ideas and thoughts about concepts important for the understanding of social pedagogy. The discourse is utopian and normative in nature; it is not concerned with practical activities. Instead, the interest is directed towards how things 'ought' to be. Within this discourse, thoughts on the historical roots of ideas can be found. Objects of social pedagogical knowledge are other parts of the discourse as well as an argument for the significance of different theories for the meaning of social pedagogy. The particularistic discourse, however, is grounded in the social pedagogical professions and organisations. This discourse contains many elements that describe where, how and why social pedagogues do what they do in the practice of practical activities (Eriksson, 2006, 2013). These discourses are intertwined, and the practical professional activities presuppose the theoretical frame and vice versa.

The theories and the history of ideas are linked to what we call the universalistic discourse. In Sweden Eriksson (2006, 2010) and Cedersund et al. (2019a) studied the history of ideas or the philosophical roots of social pedagogy. In Eriksson's research, she found that the roots are diverse. Three different traces were discovered.

The first trace that was uncovered was German social philosophy with Natorp (1940) as a representative. Natorp talked about a good society in which everyone should be integrated or participate. If someone was outside society, social pedagogy was the tool to use to get them involved or integrated again. Society is assumed to be something good and something that everyone wants to be a part of.

The second trace was the Latin American pedagogy with Freire (1972) as a primary figure. His ideas were that people were immersed in the culture of silence but through a mutual dialogue they could be made conscious of their own situation. Freire created a 'pedagogy of the oppressed'. He wanted people to be mobilised and have the opportunity to have their voice heard.

The third trace emanates from the American social work represented by Jane Addams (1910). Addams became known for her Hull House and for the Settlement Movement. Addams was a researcher, activist and politician and strove for a just society for all people. A slightly different way of describing the historical roots of ideas is to talk about a philosophical, a sociological and a pedagogical starting point (Cedersund et al., 2019a). In this method of reasoning, the roots of social pedagogy are traced by taking a starting point in three different knowledge bases. The strongest, most influential of these, and also the one that probably distinguishes social pedagogy from, for example, social work, is the philosophical knowledge base. From this, social pedagogy has drawn inspiration and knowledge, not least when it comes to Bildung processes.

Several other researchers emphasise the philosophical basis as important for social pedagogy (see, for example, Schugurensky, 2014). Here, social pedagogy has its 'own' philosophers. Natorp is an example (see Eriksson and Markström, 2000). Within the research world, but also among practising welfare workers, there is no consensus about its roots in the history of ideas. However, many researchers and practitioners believe that one of these traces weighs heavier than the others. The different traces 
have different consequences for goals and for practical work, but they also become visible in the programme (Cederlund et al., 2020; Eriksson, 2006). Discussions about a background in the history of ideas do not seem to be as common in social work. There, they have borrowed their ideological framework from Christianity, philanthropy, feminism, socialism and even fascism. This is conveyed and is most clearly expressed in social work programmes (Lorenz, 1994). When it comes to social work in Sweden and its background in the history of ideas, this may not be described in the same concentrated way as in social pedagogy. Research on social work seems to have been more focused on its practice. However, there are studies that touch on its roots in philosophy or the history of ideas, and various researchers have written about the ideas behind the history of social work (see, for example, Soydan, 1993). There are a lot of different ways of describing and understanding social work and its development (e.g. Meeuwisse and Swärd, 2016; Qvarsell, 2003; Soydan, 1993), and there are different perspectives among researchers regarding the history of ideas as it relates to this discipline. The situation is thus reminiscent of the social pedagogical one. One way to describe this is to relate the history of ideas for social work to the following.

- Special criteria or special definitions. You determine definitions and then you try to derive them historically. An objection to this approach is that social work is not based on a uniform definition.

- Special front figures such as Jane Addams and Mary Richmond, who in some contexts are portrayed as the mothers of social work. The history of ideas can also be related to different tendencies of ideas and is perhaps most commonly linked to the development of philanthropy, and its activities in England. The problem here is that the story is so complex that it cannot be explained on the basis of any single front figure or flow of ideas. Some of these front figures are common to social work and social pedagogy.

- The concept of social work is linked to actual use; social work is thus context-bound. (Meeuwisse and Swärd, 2016)

Soydan (2012), a researcher previously active in Sweden who has studied the historical origin of social work, wrote:

In this context, I have carved out two tendencies in the history of ideas: from theory to practice and from practice to theory. Second, I want to illustrate the nature of the causes of social problems. Historically, two polarized concepts manifested themselves: society generates social problems and the individual generates social problems. It is both possible and productive to carve out ideal - typical variable values, and consequently perform a dichotomization for analytical purposes. (p. 477)

Another Swedish attempt to discuss these roots in the history of ideas has been made by Swedner (1996). He took as his starting point a number of rules of action that, according to him, are obvious to anyone who is involved in working for change or whose purpose is to support and help people in vulnerable positions. For each of these rules of action, a researcher is identified who has been of great importance for its development. This way of deriving the roots has similarities with the 'Special criteria or special definitions' point above. Among the researchers whom he mentions are, for example, Freire, as a representative of the principle of consciousness, Alinsky, representing the principle of struggle, and Habermas, the principle of emancipation. Research on the history of ideas in the disciplines can be found in both social pedagogy and social work. What is obvious and distinguishes them, however, is that this research is still current and ongoing in social pedagogy (Cedersund et al., 2019a), while there seems to be a lack of discussion about these roots in the history of ideas that are found in research on social work today.

\section{Theories}

When historical roots of ideas are considered, one can also think about theories that in different ways may increase the understanding of social pedagogy and social work. As far as social pedagogy is concerned, theories have been developed in connection with other disciplines. A majority of researchers agree that any theory that is purely social pedagogical does not exist; in that sense social pedagogy is eclectic. According to earlier research, it has been found that three levels of theories occur in social pedagogy.

- The first level of theories is used in different treatment methods: method theories. As an example, theories that form the basis for different treatment methods, motivational interviewing, etc. 
- The second level is theories as explanatory models. These can, for instance, explain the emergence of social problems. They are about identifying relationships between cause and effect. The concept of stigma is an example.

- The last level consists of theories that are used as a point of reference and could be seen as descriptions and reflections on different value platforms. Examples of these are theories of democracy and about the welfare state. The individual social pedagogue's values, societal views and knowledge also determine which explanatory theories, for example, she prefers and chooses to act on. (Eriksson, 2014)

Research has recently shown that theories that are embedded in different working methods tend to take up more and more space. In a study in which professional social pedagogues were interviewed, the presence of theories at this level was common. Conversely, they did not seem, to any great extent, to rely on theories as points of reference in their work. Recent studies have established a division between value-based theories, theories with an explanatory value and theories relevant to practical social pedagogical work (Cederlund et al., 2020).

Theories in the discipline of social work have a similar position. When social work as a discipline was established one assumed that this discipline would be linked to theories and methods in other subjects (Nygren, 2006). Swedner, who was the first professor of social work in Sweden, said that social workers should be active actors and not observers. According to him, the question of identifying a theoretical core within the discipline that only belonged to social work became subordinate. It is rather a question of certain concepts with theoretical meanings that can provide a clue about a theoretical core. Examples of such concepts can be social problems and a holistic view (Swedner, 1996).

In social pedagogy the basic concepts of the discipline are discussed as well. It has been claimed that some concepts have a special bearing on the understanding of social pedagogy. Community and Bildung are two such examples (Eriksson, 2006) that have both gained relevance in recent years (Cedersund et al., 2019a; Eriksson, Nilsson and Svensson, 2013). The concepts that are important in a specific area develop and change over time. The concept of community, for example, had a particular meaning when Natorp regarded the whole society as the community. Today community has a different meaning: each individual belongs to many different communities. These are now communities that do not automatically provide security for the individual. The concept of Bildung has also a changed meaning over the years and varies depending on person, country, time and context (Gustavsson, 1996).

In social work and social pedagogy, there are several basic concepts that are important for the understanding of these disciplines. The same basic concepts are often found in both fields. Concepts that do not seem to be less common in social work but are central to social pedagogy are Bildung and community. These concepts gain their meaning in that they have historical starting points for ideas that are discussed and applied in both research and practice. A recently published book pays special attention to the concept of Bildung, and develops a social pedagogical theory based on this concept (Cedersund et al., 2019a).

\section{Research}

In Sweden there is no university with a formally organised research environment in social pedagogy, as there is for social work. This means that it is difficult to get an overview of social pedagogy as a field of knowledge. However, several current research projects focus on social pedagogy and much research in the form of articles, reports and books has been published. In the published research, which for the most part is qualitative, we can see a dividing line between research with a focus on theory and conceptual investigation, and a more work-oriented, professional focus. The dividing line is not razor-sharp and there is research that covers both approaches. The more theoretically oriented research has primarily been based on various concepts that are considered to have a bearing on the understanding of social pedagogy. It consists of research with a mainly philosophical and historical perspective (see, for example, Cedersund et al., 2019a; Cedersund, Eriksson, Ringsby Jansson and Svensson, 2019b; Eriksson, 2010). Research with a focus on practice has largely been about issues such as the relationship between social pedagogues and clients, the profession and different social pedagogical target groups or tools used by professionals (see, for example, Berglund, 2000; Bolin and Molin, 2018; Molin, 2004; Ringsby Jansson, 2002; Severinsson, 2010; Svensson, 2006). 
A recently completed research project can be considered as partially theory-generating (Cederlund et al., 2020). In this project, where active social pedagogues were interviewed, the researchers further elaborated on a previously developed theoretical model for an understanding of the meanings of social pedagogy. This previously developed model consists of three different ways of understanding social pedagogy based on key concepts, approaches, tools and methods (Eriksson, 2006, 2010). The different ways of understanding are called the adaptive, the mobilising and the democratic. These are now supplemented by the pragmatic. This means that social pedagogues who are active in the welfare sector today find it almost impossible to work on the basis of an approach and a set of values that are judged to be fully in the realm of social pedagogy. Instead, in every situation, they are forced to become pragmatic. They do the best they can based on the prevailing conditions. This recent research shows that new conditions affect and reshape social pedagogical thinking and action. The research can, from one perspective, be described as research on social pedagogy, its history and fields of knowledge. In recent years, some research has been conducted that can rather be described as research in social pedagogy. This means research that concerns issues central to social pedagogy, but which may not always be published with reference to social pedagogy. Instead it might be about phenomena such as inclusion, exclusion, globalisation and so on. It is research that focuses on processes and structures that hinder or create opportunities for participation in an increasingly changing society. The sectors and aspects of society that have been researched in this context are, for example, schools, prisons and integration activities.

Research in social work is significantly more extensive than the field of research in social pedagogy. It also makes social work research more complicated to describe. One way of bringing to light issues raised in social work research is to highlight the focus of dissertations presented within this discipline. Dellgran and Höjer (2011) provided an overview of the doctoral dissertations in social work that were published in Sweden between 1999 and 2009. Their article summarises the areas and theoretical and methodological approaches of these dissertations $(N=164)$. The areas found in this presentation have been categorised under the following headings. The number of dissertations in each area is also stated.

- Social working methods, 60

- Social phenomena and problems, 55

- Client groups, 38

- Social law and organisation, 11

A predominant portion of the analysed dissertations had a clear connection to an area of activity within social work practices. The area of activity that had the most published dissertations was social care (both elderly care and disability care - a total of 33 dissertations). The second-largest area concerned social care for children and young people (23 dissertations). A small number of dissertations dealt with substance abuse care (12), income support (15) and health care (12), while a few more contained studies pertaining to individual and family care in social services. With regard to the methodological approach of the dissertations, there was either quantitative or qualitative research and in some dissertations a combination of both approaches.

Dellgran and Höjer's analysis of the dissertations' theoretical orientation shows that the subject of social work is characterised by pluralism, but that there is significant influence from sociology and psychology. Among the theorists mentioned are many names in sociology classics (Durkheim, Simmel, Tönnies) and more modern classics (Foucault, Goffman). In the field of organisational theory, there are names such as Hasenfeldt and Lipsky, while theorists who focus on late modern society include Bauman and Beck. In another analysis carried out by Högström (2018) with a focus on social pedagogical texts, it emerged that Goffman was the author who was referred to most frequently.

The analysis of dissertations in social work from the previous decade reported by Dellgran and Höjer (2011) clearly shows that research in social work during the period examined has in various ways focused on studies of practices. In our own review of research in social work in recent years, these practice-related topics are common also in current research. The interplay between education, research and practice also appears to be concerned with central issues in social work as an area of knowledge and research. Areas that are central to socionom studies and socionoms' internships are often in the spotlight in social work research. Research competencies related to different aspects of social work are in focus when the quality of this academic discipline is examined. In order to conduct programmes in social work, it is required that the schools of social work have teaching and research staff with competence in the core areas identified in social work. Active research in social work offers a way to ensure that the academic 
level of the programme is characterised by good quality. However, this closeness between education, research and practice can be both a strength and a weakness. The knowledge produced in research can provide an important insight into the practices of social work, but the closeness between education, research and practice can also mean that the distance between them is reduced. Research on social work risks being reduced in scope in cases where the active researchers come mainly or exclusively from their own profession. However, such a one-sided perspective from within the profession is not at present characteristic of research in social work. Some of those who conduct the research have backgrounds as socionoms, but many of the researchers have an academic background in other social science disciplines.

\section{Social pedagogy and social work in practice}

Social pedagogues work under different levels of leadership in the welfare sector, such as municipal, state, regional and private organisations (Eriksson and Hedman, 2018). Many work as civil servants in municipal individual and family care, elderly care and disability care. Others work as managers in elderly and disability care. Some work with special functions as counsellors in schools or as pedagogues in various forms of housing or day activities. In the state sector, they work at the Swedish Social Insurance Agency and the Employment Service. In the private sector, for example, they work in care homes or residential homes. Cederlund et al., (2020) showed that social pedagogues work with people of different ages. They can be adults with neuropsychiatric disabilities and young people or families with social problems. At school, there are students in need of special support. In the state sector, it may be young people who have recently arrived in Sweden, or young adults with social problems.

In the study by Cederlund et al. (2020) respondents report difficulty in describing characteristic methods for social pedagogical work. Work starts with a meeting between the social pedagogue and those who are in need of help and support. Social pedagogical work is described as an ongoing process in the sense that there are no ready-made methods that can be applied. An important aim of social pedagogical working methods is, in addition to creating conditions for growth, the emphasis on inclusion in social communities. The study shows that social pedagogues work with both individualand group-oriented methods.

The individual-oriented methods include conversations that were both a way to meet and a way to investigate and support those who were in need of assistance. It can also be about performing practical activities in everyday life together or assisting with activities that the person seeking help perceives as difficult; these might include different types of practical tasks at home, helping to look for work or being involved in a legal dispute.

The group-oriented working methods are of various kinds and could be understood as based on the concept of 'the common third' (Lihme, 2012). It is about doing something together, experiencing or performing a task together. It is something that is outside their problems - that is, 'the third'. An example is when a social pedagogue together with a group of young people with social or relation problems play floorball once a week. The activity serves as something to do together and while they play, they communicate. The social pedagogue does not pressure the young people to do so; taking part in the sport together means it happens naturally. These young people often prefer not to talk about personal matters or family problems and prefer to have something physical to do together. The group-oriented activities described in the study (Cederlund et al., 2020) are a way of doing things together and could be about preparing a joint meal, taking a walk or attending a sporting event or a cultural activity together. $\mathrm{A}$ special form of group method is aesthetic activities in the form of artistic creation, writing texts, producing films or preparing to participate in an exhibition together. These social pedagogical methods based on both individuals' and groups' everyday arenas aim to create conditions for growth in those who are in need of help and support (Cederlund et al., 2020).

When it comes to what tasks socionoms work with, this largely depends on what position he or she holds. Bengtsson's study (2020) shows that the socionom profession covers a multifaceted area of work, which has meant that it can be difficult to carry out a categorisation of their tasks. He states that socionoms work as social workers, counsellors at hospitals or schools, heads of units, development assistance assessors and family therapists.

To report which methods are used in social work, we refer, among other things, to Bergmark and Lundström (2016). The conclusion they draw from their research is that when questions about methods are asked of professional socionoms, the answers vary over time. In a previous study (Bergmark and 
Lundström, 1998), social workers most often responded with networking, solution-focused methods and motivational work. In a more recent study (Lundström and Shanks, 2013), three-quarters of the respondents answered that they work with evidence-based methods. It thus seems that new methods, based on evidence-based thinking, have made an impact in the professional practice of socionoms over the past decade or so. Different working methods are often emphasised as being important when it comes to characterising the practice of social work. One type of method that has existed for a long time is called case work. Case work as a working method was introduced in Sweden following an American model, and when it was transferred to the Swedish context it was called social care methodology. This methodology has gradually been replaced by approaches that have gone under headings such as family therapy, group therapy and crisis therapy. During certain periods, from the 1970s onwards, specialisations in community work have also had their place in social work and in the education of socionoms (Pettersson, 2017).

Descriptions of the emergence of the socionom profession in Sweden also often point to the close connection between social work and social policy (Swärd, 2017). When the socionom profession was formed, there was also a desire for this profession to meet the need for skills that were requested in emerging municipal and state bureaucracies. This picture of social work filled with administrative tasks is made with reference to Lorenz's (1994) descriptions of the growth of social work in the Scandinavian countries, which point to a development of municipal policy models where decisions are made by local committees and by socionoms as servants of the welfare system.

\section{Some similarities and differences}

There are large overlaps in terms of the two professional fields and the content of their work. Even when it comes to how the work is performed, there are many similarities between how social pedagogues and socionoms work. However, there seems to be a greater element of group-oriented work among social pedagogues (Cederlund et al., 2020; Eriksson and Hedman, 2018).

Socionoms, by contrast, seem to have a greater element of administrative, bureaucratic content in their professional practice (cf. Swärd, 2017). Legislation regulating work that includes the exercise of authority over children and young people states that it must be socionoms who work in this area. Social pedagogues work primarily with groups of the elderly and people with disabilities when it comes to exercising authority. What can be noted in the referenced study by Cederlund et al. (2020) is that there is a kind of 'methodical approach' that could be seen as characteristic of social pedagogical work. The most distinctive feature was that the current situation leads to a certain way of working and that this emerges in the relationship and meeting between the social pedagogue and the individual. A conclusion drawn based on the collected data material was therefore that social pedagogical methods, to a large extent, strive to build on the genuine meeting, which is created through good relations between the individual and the social pedagogue. Bergmark and Lundström (2016) emphasised, however, that the concept of meeting has become increasingly important in social work. The basic idea is then that it is increasingly an important matter to create well-functioning meetings between the socionom and the people who are in need of help and support. Emphasising the importance of meetings between professionals and clients/citizens thus occurs among both socionoms and social pedagogues.

Overall we can see that both social work and social pedagogy are interdisciplinary and have a significant origin in sociology. Social pedagogy, however, has its origins also in pedagogy/education to a greater extent than social work. Today, in terms of practice, many social pedagogues also have investigative, assessment and leading tasks as part of their remit.

\section{Summary reflections}

Social pedagogy and social work are disciplines without consensus on their theoretical or practical basis, neither among researchers nor practitioners. Today, comparisons between social work and social pedagogy are not often made, as such contrasts are not perceived as very significant. There are, however, some areas where it is possible and meaningful to describe the differences between the two. It is primarily about educational history and current programmes. Here the differences are clear and readily identifiable, but there are also differences in terms of their roots in the history of ideas and theory. 
Social work, in contrast to social pedagogy, has a given place in the Swedish academic system. The social work programme has consolidated its role in the academic system. This programme leads to a vocational degree - socionom. The situation concerning social pedagogy is completely different. Social pedagogical courses and programmes started at a level close to practice, had an interlude at universities and colleges, but now, to a large extent, are back outside academia. The lack of a regulated social pedagogical programme at the academic level entails several disadvantages. A sense of belonging and identity is created through a programme that provides a common foundation to stand on. Through research-based teaching, the theoretical and philosophical basis of the discipline is conveyed to the students, which lays the foundation for the professional identity developed in their working lives. For former students of social pedagogy, philosophers like Natorp and Freire have been a central part of the teaching content. In social work studies it is less common to focus on content relating to the history of ideas. There is also a difference in research in these areas. Current social pedagogical research has been more focused on an understanding of the discipline in terms of the history of ideas rather than with regard to research in social work. This becomes clear in the review of dissertations in social work by Dellgran and Höjer (2012). A few decades ago, research might focus on the historical roots of ideas in social work, but more recently research has been dominated by social methods. This says something about developments in the area of social welfare and what is considered important. Evidence-based and manual-driven methods have increasingly come to dominate the discussion about social work, at least in official writings and documents (Rehnman and Kumlin, 2020; SOU, 2020, p. 47). Concepts central to a discipline also determine, together with their grounding in the history of ideas, the direction, content and practical expression of that discipline. In social pedagogy one of the most characteristic concepts is Bildung, which, in recent years, has had a major impact on the understanding of the field. It is connected to the history of ideas in which social pedagogy is grounded, but in social work is not at all central. The aim of the programme is to educate the students for a future professional life.

Today, there are some differences between professional social pedagogues and socionoms. For example, social pedagogues have a greater propensity for group-oriented work and place less emphasis on administrative and bureaucratic aspects of their profession. When former social pedagogy students are interviewed, these differences in professional identity are revealed. There is also some hesitation towards evidence-based methods.

The professional pride and feeling of being 'someone other' than a socionom is something that social pedagogues in various contexts have expressed. We suspect that this way of thinking about one's own profession as something other than a socionom will disappear when only a few academically trained social pedagogues undergo higher education-level training in social pedagogy.

Students, like everyone else, are influenced by education and other life contexts. The current differences between social work and social pedagogy will probably disappear in the long run. It is worth noting that at the same time as this process is going on, employers in Sweden have begun to show an interest in employing social pedagogues.

An understanding of social pedagogy as mostly treatment work is an attitude that prevailed in Sweden for about 20 years until the 1990s when the concept gained a broader meaning, thanks to researchers becoming interested in the potential of social pedagogy. With the de-academicisation of programmes of social pedagogy, there is a risk that there will be a return to the situation when treatment work was the dominant content in social pedagogues' education. There is not much opportunity for non-academic programmes to conduct teaching on a scientific basis.

The future of social pedagogy may seem problematic, at least if we place our focus on the educational situation. But the development can also go in another direction, too. We think that social pedagogy as a system of thought, with its philosophical roots and humanistic values, can hold the promise of potential developments in both present and future welfare work in Sweden.

The current challenges of the welfare state, the societal crises, difficulties and problems that characterise our times, such as the refugee issue, the climate crisis, the consequences of globalisation and most recently the COVID-19 pandemic, show that we need new knowledge, other ways of thinking and understanding our times, and that not everything can be reduced to and understood by the use of already known and well-defined methods with predictable results. In this situation, where our routines are disrupted and what we previously took for granted is no longer self-evident, philosophy becomes increasingly important. The Swedish philosopher Bornemark (2020) has delivered a polemic against the fact that welfare work is increasingly focused on what is possible to measure and document. In crises we have to act even though we do not know everything. What is new cannot be met with 
evidence-based knowledge, she says, and with reference to Aristotle and Arendt, she points to the possibility of highlighting concepts such as judgement and respect for unpredictability more clearly in social welfare work. Eichsteller and Brad (2019) also discussed the importance of paying attention to the unpredictability of social and social pedagogical work. Complex situations have both predictable and unpredictable consequences; some are obvious immediately and others we discover much later, they suggest. An open approach enables us to see new solutions. In situations where there is no obvious answer, you must first probe, feel for and try your hand at it.

Possessing good judgement, Bornemark says, is closely connected to our ability to deal with ignorance, capture what is important and be able to act in a situation where everything is not as it usually has been. Here we see that an education in social pedagogy and Bildung can play an important role, opening up for welfare work where reflection on unique situations in professional work provides an opportunity to develop new knowledge and skills where the polarisation between theory and practice can be bridged. In this context, social pedagogy has a given role. The question is whether an in-depth collaboration between social pedagogy and social work can be a way of making space for the immeasurable.

\section{Author biographies}

Elisabet Cedersund received her PhD in communication studies from Linköping University in 1992. She has been professor of social work at Jönköping University (2006-11), and professor of ageing and later life at Linköping University (2011-16). She has conducted research on the client-social worker encounter, and on interaction between older people and professionals in health and social care. Many of her studies deal with human interaction in various types of casework where oral communication is used as the basis for decision making, and with how the construction of 'social problems' and 'care needs' in talk contributes to a deeper understanding of how cases are managed in welfare work and elder care. She has been the coordinator of several research networks in social work and social pedagogy with the goal of developing and strengthening the cooperation between researchers in the Nordic countries. Since 2016 she has been Professor Emerita at Linköping University.

Lisbeth Eriksson has worked as a social worker for 17 years in various fields such as social services, the prison and correctional sectors, and hospital care. She received her PhD in educational sciences from Linköping University in 2002 and became an associate professor at the same university in 2007. Her research has two different focuses: one is on immigrants, the multicultural society and popular education, and the other is on social pedagogy. Her research in the field of social pedagogy includes theoretical issues and the meanings and understandings of social pedagogy. She has written several articles and books about popular education and social pedagogy. Currently she is working as a researcher at the Division of Social Work and Social Pedagogy at University West in Trollhättan.

Bibbi Ringsby-Jansson has a professional background in disability care for people with learning disabilities. For several years she has worked as a university lecturer within the programme of Social Work and Social Pedagogy, and has been head of unit at the Division of Social Work and Social Pedagogy at University West in Trollhättan. She received her PhD in social work from the University of Gothenburg in 2002. Her research interest is focused on two main areas: social life and the importance of participation in the local public environment for young people with learning disabilities, and social pedagogy as theory, activity and as a research area, related to the field of disability care. She has written articles and book chapters on how social life, working life and living conditions are influenced by spatial design and organisation of housing, neighbourhoods and the local public environment for young people with disabilities. Currently, she is working as a researcher and university lecturer at University West in Trollhättan.

Lars A. Svensson has a professional background in municipal elder care and worked for several years as director of a home for older people. Between 1985 and 2016, he taught at University West in the Social Work and Social Pedagogy programme. His teaching focus was on older people, ageing and elder care. He received his PhD in social work from the University of Gothenburg in 2006. His current research has two different focuses: one is on the importance of meeting places in the neighbourhood for older people; the other is on social pedagogy as a theoretical concept, practical activity and education, and how it can be applied to the field of social gerontology. He has written several articles and has 
contributed to books about the importance of meeting places for older people and social pedagogy. Currently he is an affiliated researcher in social work in the Division of Social Work and Social Pedagogy at University West in Trollhättan.

\section{Notes}

${ }^{1}$ Socionom is the professional qualification received when one completes a social work educational programme for three and half years ( 210 credits); in international contexts the term social worker is used. The academic qualification is BSc in Social Work (UHR, 2020).

${ }^{2}$ At Linnaeus University in Växjö, there is an academic social pedagogical course, Social Pedagogy with a Specialisation in Youth at Risk and Adults with Substance Abuse, worth 180 credits, which leads to a bachelor's degree in Pedagogy. Also at Malmö University there is a social pedagogical course, Social Pedagogical Work in the Field of Disability, also worth 180 credits, which leads to a BSc with a Major in Disability and Rehabilitation Science.

${ }^{3}$ In the article, we use the terms 'social workers' and 'welfare workers' in parallel. If we mean social pedagogues or socionoms specifically, we state that.

\section{Declarations and conflict of interests}

The authors declare no conflicts of interest.

\section{References}

Addams, J. (1910). Twenty years at Hull House. London: Macmillan.

Bengtsson, M. (2020). Karriär och profession. Om positioner, statushierarki och mobilitet inom socionomyrket. Dissertation, Lund University.

Berglund, S. A. (2000). Social pedagogik - I goda möten skapas goda skäl. Lund: Studentlitteratur.

Bergmark, Å., \& Lundström, T. (1998). Metoder i socialt arbete. Om insatser och arbetssätt i socialtjänstens individ- och familjeomsorg. Socialvetenskaplig tidskrift, 5(4), 281-314.

Bergmark, A, \& Lundström, T. (2016). Metoder i socialt arbete - vad är det? In A. Meeuwisse, H. Swärd, S. Sunesson \& M. Knutagård (Eds.), Socialt arbete. En grundbok (pp. 290-9). Stockholm: Natur \& Kultur.

Bolin, A., \& Molin, M. (2018). Socialpedagogisk handling - i teori och praktik (Rapport Högskolan Väst Nr 2018: 4). Trollhättan: University West.

Bornemark, J. (2020). Horisonten finns alltid kvar. Stockholm: Volante.

Brante, T. (2005). Om begreppet och företeelsen profession. Tidskrift för Praxisnära Forskning, 1, 171-82.

Cederlund, C., Eriksson, L., Ringsby Jansson, B., \& Svensson, L. A. (2020). I huvudet på en socialpedagog. en studie om yrkesverksamma välfärdsarbetare och deras föreställningar om socialpedagogik (Rapport Högskolan Väst Nr 2020: 3). Trollhättan: University West.

Cedersund, E., Eriksson, L., Ringsby Jansson, B., \& Svensson, L. A. (2019a). Renässans för socialpedagogik. En bok om socialpedagogisk bildning. Lund: Studentlitteratur.

Cedersund, E., Eriksson, L., Ringsby Jansson, B., \& Svensson, L. A. (2019b). Social pedagogical practices in Swedish welfare contexts. International Journal of Social Pedagogy, 7(1), 1-12. [CrossRef]

Dellgran, P., \& Höjer, S. (2011). Nya trender och gamla mönster. Doktorsavhandlingarna i socialt arbete 1980-2009. Socialvetenskaplig tidskrift, 18(2), 85-106.

Dellgran, P., \& Höjer, S. (2012). The politics of social work research: Ph.D theses in Sweden. European Journal of Social Work, 15(4), 581-97. [CrossRef]

Eichsteller, G., \& Brad, L. (2019). The context for social professions across Europe. In G. Eichsteller \& L. Brad (Eds.), Social pedagogy as a meaningful perspective for education and social care. Beaumaris: ThemPra Social Pedagogy.

Eriksson, L. (2006). 'Socialpedagoger utan gränser' - en studie om socialpedagogiska innebörder (Skapande vetande 47). Linköping University.

Eriksson, L. (2010). A Swedish way of teaching citizenship to immigrants - popular adult education as a social pedagogical activity. In L. Eriksson \& T. Winman (Eds.), Learning to fly. Social pedagogy in a contemporary society (pp. 119-39). Gothenburg: Daidalos. 
Eriksson, L. (2013). Mobilisering för kollektiv självutveckling - en teoretisk ram. In L. Eriksson, G. Nilsson \& L. A. Svensson (Eds.), Gemenskaper. Socialpedagogiska perspektiv (pp. 23-46). Gothenburg: Daidalos.

Eriksson, L. (2014). The understandings of social pedagogy from northern European perspectives. Journal of Social Work, 14(2), 165-82. [CrossRef]

Eriksson, L., \& Cederlund, C. (2015). Socionomers yrkesval. En studie av socionomer examinerade vid Stockholms universitet under 2012 och våren 2013. FoU-Nordväst and Stockholm University.

Eriksson, L., \& Hedman, L. (2018). 'Var finns socialpedagogerna?' Yrkestitlar, fält och socialpedagogisk förankring (Forskningsrapport 2018: 1). Campus Västervik.

Eriksson, L., \& Markström, A. M. (2000). Den svårfångade socialpedagogiken. Lund: Studentlitteratur.

Eriksson, L., Nilsson, G., \& Svensson, L. A. (Eds.). (2013). Gemenskaper. Socialpedagogiska perspektiv. Gothenburg: Daidalos.

Freire, P. (1972). Pedagogik för förtryckta. Stockholm: Gummeson.

Gustavsson, B. (1996). Bildning i vår tid. Om bildningens möjligheter och villkor i det moderna samhället. Stockholm: Wahlström \& Widstrand.

Harding, T. (2012). Framtidens civilsamhälle (Underlagsrapport 3 till Framtidskommissionen). Stockholm: Fritzes.

Högström, M. (2018). What is the Swedish interpretation of social pedagogy? A literature review. Papers of Social Pedagogy, 8(1), 51-65.

Lihme, B. (2012). Det fælles tredje - en personlig faghistorie om socialpædagogikkens identitet i en trængselstid. Tidsskrift for Socialpædagogik - Tema: Det fælles tredje, 15(2), 5-10.

Lorenz, W. (1994). Social work in a changing Europe. London and New York: Routledge.

Lundström, T., \& Shanks, E. (2013). Hård yta men mjukt innanmäte. Om hur chefer inom den sociala barnavården översätter evidensbaserat socialt arbete till lokal praktik. Socialvetenskaplig tidskrift, 20(2), 108-26.

Madsen, B. (2006). Socialpedagogik - Integration och inklusion i det moderna samhället. Lund: Studentlitteratur.

Meeuwisse, A., \& Swärd, H. (2016). Vad är socialt arbete? In A. Meeuwisse, S. Sunesson \& H. Swärd (Eds.), Socialt arbete. En grundbok (pp. 29-76). Stockholm: Natur \& Kultur.

Molin, M. (2004). Att vara i särklass - om delaktighet och utanförskap i gymnasiesärskolan. Dissertation, Linköping University.

Natorp, P. (1940). Sozialpädagogik. Stuttgart: Frammans.

Nygren, L. (2006). Socialt arbete som ämne. In A. Meeuwisse, H. Swärd \& S. Sunesson (Eds.), Socialt arbete. En grundbok (pp. 303-18). Stockholm: Natur \& Kultur.

Nygren, L. (2016). Socialt arbete i praktik, forskning och utbildning. In A. Meeuwisse, S. Sunesson \& M. Knutagård (Eds.), Socialt arbete. En grundbok (pp. 128-45). Stockholm: Natur \& Kultur.

Pettersson, U. (2017). Från filantropi till profession. Utvecklingen av socialt arbete i Sverige och USA. In H. Swärd \& G. Edebalk (Eds.), Socialt arbete och socialpolitik. Om Centralförbundet för socialt arbete och dess betydelse (pp. 260-93). Lund: Studentlitteratur.

Qvarsell, R. (2003). CSA och socialpolitiken kring sekelskiftet 1900. Socialvetenskaplig tidskrift, 10(2-3), 117-30. [CrossRef]

Regeringens Proposition. (1978/79). Om vårdutbildning inom högskolan. (prop. 1978/79: 197). Regeringen.

Rehnman, J., \& Kumlin, J. 2020. Ökat intresse för evidensbaserad praktik - men utmaningar finns. Socionomen.

Ringsby Jansson, B. (2002). Vardagslivets arenor: om människor med utvecklingsstörning, deras vardag och sociala liv. Dissertation, University of Gothenburg.

Sandermann, P. (2014). Change and continuity in western welfare practices: Some introductory comments. In P. Sandermann (Ed.), The end of welfare as we know it? Continuity and change in Western welfare state settings and practices. Opladen: Barbara Budrich Publishers.

Schugurensky, D. (2014). A social worker, a community development worker and an adult educator walk into a bar: On strange bedfellows and social pedagogy. Postcolonial Directions in Education, 3(2), 360-95.

Severinsson, S. (2010). Unga i normalitetens gränsland. Undervisning ochbehandling i särskilda undervisningsgrupper och hem för vård eller boende. Dissertation, Linköping University.

SOU 2020: 47. (2020). Hållbar socialtjänst - En ny socialtjänstlag. Slutbetänkande av Utredningen Framtidens socialtjänst. Accessed 14 September 2021. https://www.regeringen.se/rattsligadokument/statens-offentliga-utredningar/2020/08/sou-202047/. 
Soydan, H. (1993). Det sociala arbetets idéhistoria. Lund: Studentlitteratur.

Soydan, H. (2012). Understanding social work in the history of ideas. Research on Social Work Practice, 22(5), 468-80. [CrossRef]

Sunesson, S. (2003). Socialt arbete - en bakgrund till ett forskningsämne. In B. Bergseth (Ed.), Socialt arbete; en nationell genomlysning av ämnet (Högskoleverkets rapportserie 2003:16 R). Stockholm: Högskoleverket.

Svensson, L. A. (2006). Mötesplatser på landsbygden: om äldre människor, gemenskaper och aktiviteter. Dissertation, Gothenburg University.

Swärd, H. (2017). Vad kan en organisation berätta om socialt arbete och socialpolitik? Centralförbundet för socialt arbete mellan två sekelskiften. In H. Swärd \& P. G. Edebalk (Eds.), Socialt arbete och socialpolitik. Om Centralförbundet för socialt arbete och dess betydelse (pp. 38-101). Lund: Studentlitteratur.

Swärd, H., \& Edebalk, P. G. (Eds.). (2017). Socialt arbete och socialpolitik. Om Centralförbundet för socialt arbete och dess betydelse. Lund: Studentlitteratur.

Swedner, H. (1996). Socialt välfärdsarbete. En tankeram. Stockholm: Liber.

Thörn, K. (2017). CSA:s utbildningskurs för praktiskt socialt arbete och Stockholms socialinstitut. In H. Swärd \& P. G. Edebalk (Eds.), Socialt arbete och socialpolitik. Om Centralförbundet för socialt arbete och dess betydelse (pp. 214-41). Lund: Studentlitteratur.

UHR. (2020). Studera.nu. Stockholm: The Swedish Council of Higher Education. Accessed 14 September 2021. https://www.studera.nu/jamfor-utbildning/socionom. 